Nat. Hazards Earth Syst. Sci. Discuss., https://doi.org/10.5194/nhess-2018-21

Manuscript under review for journal Nat. Hazards Earth Syst. Sci.

Discussion started: 31 January 2018

(c) Author(s) 2018. CC BY 4.0 License.

\title{
The Quick Assessment Model of Casualties for Asia based on the Vulnerability of Earthquake
}

Yue Zhang, Qigen Lin, Yanyi Liu, Ying Wang

Key Laboratory of Environmental Change and Natural Disaster of Ministry of Education, Beijing Normal University, 5 Beijing, 100875, China

Correspondence to: Ying Wang (wy@bnu.edu.cn)

\begin{abstract}
In order to make a scientific emergency strategic decision after an earthquake, casualties need to be estimated rapidly. Asia is the most earthquake-prone continent in the world. In this paper, by spatial statistic and regressive analysis of historical Asian earthquake data from 1990 to 2012, vulnerability curves portraying the empirical relationship between the magnitude of an earthquake event and the casualty rate caused by it were created for countries of six-groups and the Quick Assessment Model of Earthquake Casualties for Asia (QAMECA) was developed. The casualty rate was defined as the ratio of the sum of injuries and deaths in an earthquake to the number of people living in the earthquake-affected region. Thirtyone earthquake events from 2013 to 2016 were used to validate this model, and the validation results were good with actual casualties of twenty-one were within the range estimated by the model and the biases of eight out of ten were less than one

15 hundred percent. The two input parameters of QAMECA were magnitude and location of epicenter of an earthquake and earthquake casualties can be estimated immediately after earthquake has occurred. As a consequence, QAMECA can be used to estimate earthquake casualties for Asian countries and aid decision making in international emergency relief in the future.
\end{abstract}

\section{Introduction}

Earthquake disaster is the natural disaster that causes the most of death toll. Population vulnerability of earthquake refers to the situation caused by earthquake that affects the probability and the extent of damage (Pelling et al., 2004). With continuous growth of global population and large-scale urbanization, the threat to human safety from earthquake will be larger. Our technological level is not advanced enough to accurately predict the earthquake, but we can study the earthquake from the following two aspects, so the casualties caused by the earthquake could be reduced as much as possible. First, vulnerability assessment of earthquake disaster should be done well before the earthquake, and the construction of disaster prevention and reduction system should be strengthened in the regions with relative high vulnerability of population. Second, casualties should be estimated rapidly after the earthquake, and according to the estimated results, the reasonable rescue measures would be deployed to carry out the effective rescue. Although there are essential differences between the two aspects, they are both needed to work based on rapid earthquake casualty and loss modelling. 
Nat. Hazards Earth Syst. Sci. Discuss., https://doi.org/10.5194/nhess-2018-21

Manuscript under review for journal Nat. Hazards Earth Syst. Sci.

Discussion started: 31 January 2018

(c) Author(s) 2018. CC BY 4.0 License.

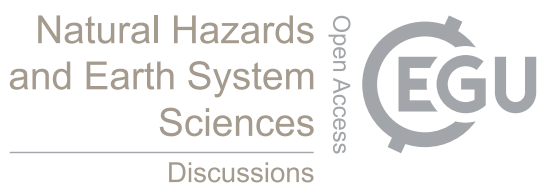

Samardjieva and Badal (2002) considered that the number of earthquake casualties should be positively correlated with magnitude, despite affected by many factors. They analysed earthquake data with focal depths of less than $60 \mathrm{~km}$ globally in the 20th century and established a logarithmic-linear model of population density between death toll and magnitude. Based on the casualty rate (injuries/deaths) and the logarithmic-linear relationship of magnitude, Christoskov and Samardjieva 5 (1984) assumed that the prediction of death toll was close to the expected accuracy, then they calculated the number of injuries by the number of deaths. Similarly, Nichols and Beavers (2003) used magnitude as an indicator of ground motion intensity. By analysing the earthquakes that took place in the 20th century such as Messina earthquake in 1908, Avezzano earthquake in 1915 and Tangshan earthquake in 1976 etc., they created a threshold curve of death toll about the magnitude in the earthquake. This threshold curve was suitable for estimating the maximum of death toll caused by an earthquake in or 10 around the city.

Jaiswal and Wald (2010) argued that seismic intensity was an indicator that measured the degree of damage to buildings caused directly by earthquake. The population exposure defined by seismic intensity (total population exposed in areas of particular intensity, such as VI and above) had greater impact to the death toll than the earthquake magnitude, so it was not reasonable to use a single magnitude as a regression parameter. Based on the case study of the Ahar-Varzaghan earthquakes

15 in Iran, Bastami and Soghrat (2016) developed a model that correlates the number of deaths, distance from epicenter to affected village and peak ground acceleration, and the results show that the number of deaths has a stronger relationship with peak ground acceleration than distance.

There are also many agencies that adopt seismic intensity to rapidly estimate earthquake casualties, for example, the PGAER System (Prompt Assessment of Global Earthquakes for Response) of the US Geological Survey (USGS), GDACS

20 System (Global Disaster Alert and Coordination System) jointly developed by European Commission's Joint Research Centre and the United Nations Office for Coordination of Humanitarian Affairs (OCHA), and the Extremum System of the Russian Academy of Sciences. Taking the PAGER System as an example, firstly the ShakeMap of seismic intensity is drawn according to the attenuation law of ground motion. Then the mortalities in different intensity regions are calculated according to the quantitative relationship between the casualty rate and the earthquake intensity. Finally, the estimated death toll is concluded through overlaying Landscan population data from the Oak Ridge National Laboratory. Among them, the intensity-casualty rate two-parameter normal distribution function was established by the regression analysis of the global earthquake disaster data from 1973 to 2007 (Allen et al., 2009a;Allen et al., 2009b;Jaiswal and Wald, 2010;Jaiswal et al., 2011). GDACS System adopts ShakeMap of USGS to simulate the intensity distribution. According to the vulnerability curve, the probability of $T$ type building under the intensity $I$ with $D$ grade damaged condition is determined. The death rate caused by the collapse of the building is calculated and the death toll is calculated with population data (Groeve et al., 2008). The principle of the Extremum System is basically the same as the GDACS System, that is, the earthquake intensity distribution is simulated according to the attenuation law of ground motion, and the damage conditions of different buildings in different intensity regions are determined, so the predicted death toll is concluded (Trendafiloski et al., 2011;Frolova et al., 2016). 
Nat. Hazards Earth Syst. Sci. Discuss., https://doi.org/10.5194/nhess-2018-21

Manuscript under review for journal Nat. Hazards Earth Syst. Sci.

Discussion started: 31 January 2018

(c) Author(s) 2018. CC BY 4.0 License. Geological Survey listed 20 largest earthquakes between 1900 and 2016 in the world, 11 of them occurred in Asia. Asia is densely populated and there are many developing countries with poor resistance to natural disasters, so casualties caused by earthquake are quite heavy. According to Emergency Events Database (EM-DAT) from the Centre for Research on the 5 Epidemiology of Disasters (CRED), there were 578 earthquakes that affected humans between 1990 and 2012. Among them, 356 earthquakes occurred in Asia, accounting for $62 \%$ of the total. China, Indonesia, Iran, Turkey and Japan are countries with most earthquakes in the world. During 23 years, the earthquake caused a total of 743,000 deaths and 1.623 million injuries worldwide. The death tolls in Asia were 506,000, and the injuries were 1,240,000. In terms of the number of earthquakes, death tolls and injuries, Asia is the worst-hit continent.

10 However, the three international earthquake disaster casualty assessment systems mentioned earlier are not developed specifically for Asian countries. At the same time, these assessment systems need to simulate the earthquake intensity distribution according to the attenuation law of ground motion. However, there would be discrepancy between simulated and actual intensity. Therefore, these systems are not accurate in assessing the casualties in the earthquakes in Asia. In this paper, by spatial statistic and regressive analysis of historical Asian earthquake data from 1990 to 2012, we established the double-

15 parameter casualties QAMECA (Quick Assessment Model of Earthquake Casualties for Asia) based on magnitude-casualty rate threshold curve for the earthquake-prone countries in Asia, and we hoped to provide a reference for pre-earthquake vulnerability assessment and the post-earthquake emergency rescue strategy.

\section{Data}

\subsection{Seismic data}

20 According to the above purposes, in this paper we collected the corresponding seismic data and built the Asian Earthquake Disaster Database. There are three main sources of data: the first source is EM-DAT (http://www.emdat.be) published by CRED. EM-DAT contains essential core data on the occurrence and effects of over 22,000 mass disasters in the world from 1900 to the present day. As one of the most important disaster databases around the world, it's widely used in fields of global disaster reduction and emergency management. Disaster events meeting one of four criteria can be complied into EM-DAT: 1) no less than 10 people killed 2) more than 100 people affected 3) declare a state of emergency 4) call for international assistance. Through the EM-DAT database, we collected the Asian earthquake disaster between 1990 and 2012. According to the time and location of the earthquake disaster, we checked the data and eliminated the repeated disaster events, and we got 356 data records. There were time, nation, location description, magnitude, death toll, number of injuries and other information recorded in detail for each of the seismic records.

30 The second data source is the Disaster Archive from Asian Disaster Reduction Center (ADRC; http://www.adrc.asia/) and GLIDE database (http://www.glidenumber.net/). The information provided in the Disaster Archive mainly includes the type of disaster, the time and location, the general situation and links to news reports related to the disaster. The GLIDE database 
Nat. Hazards Earth Syst. Sci. Discuss., https://doi.org/10.5194/nhess-2018-21

Manuscript under review for journal Nat. Hazards Earth Syst. Sci.

Discussion started: 31 January 2018

(c) Author(s) 2018. CC BY 4.0 License.

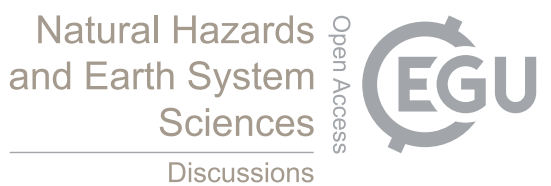

was co-founded by Asian Disaster Reduction Center and the United Nations Office for the Coordination of Humanitarian Affairs, and there is a unique and codified number for each disaster record in the GLIDE database. Disaster records include disaster codes, disaster categories, country, and disaster comments. In the case of earthquake, the disaster comments include specific time, location description, magnitude, death toll and number of injuries.

5 The third data sources are Google Earth and the reports about Asian earthquake on the Internet. The accurate latitude and longitude of epicenter was acquired through searching key words in location description on Google Earth. Accurate locations of some recent earthquake events were obtained through searching on the Internet.

The Asian Earthquake Disaster Database is based on the EM-DAT database, but due to the lack of data on the number of injuries in the earthquake disaster record between 2013 and 2016, we adopted the records from the Asian Disaster Reduction

10 Center and the GLIDE database to supplement. In order to ensure the authenticity of the records, we first compared the two sources with Asian earthquake records between 2013 and 2016, and then screened 57 records with complete information of time, country, location, magnitude, deaths and injuries. Then, do the same with location description as records from 1990 to 2012 to obtain accurate latitude and longitude of epicenter. The collected earthquake records were integrated to establish the Asian Earthquake Disaster Database.

15 The Asian Earthquake Database in this paper contains a total of 413 earthquakes records in 26 countries and regions (hereinafter referred to as the countries) from 1990 to 2016. The fields are Year, Full Name of Earthquake Country, ISO Name of Earthquake Country, Longitude of Epicenter, Latitude of Epicenter, Magnitude, Death Toll, Number of Injuries, Number of Casualties (sum of deaths and injuries). Among them, earthquake records which were used in this paper to establish and verify earthquake records of vulnerability models must meet the following two criteria: 1) Magnitude were 5.0

20 or above, 2) Number of casualties was greater than 10 people. In summary, 349 records from 1990 to 2016 covering 22 countries meet criterion 1) (Fig. 1) and 271 records from 1990 to 2016 covering 21 countries meet both two criteria.

As illustrated in Fig. 1, China, Indonesia, Iran, Turkey and Japan are five countries with most earthquake events from 1990 to 2016 and casualties are 577 thousand, 340 thousand, 215 thousand, 80 thousand and 78 thousand respectively. The number of people affected by earthquakes is far higher than casualties. For example, there are more than a hundred million

25 people affected by earthquake in China, Indonesia and Japan, which can be regarded as a further proof of extreme severity of earthquakes' effect on Asian countries.

\subsection{Demographic data}

Population data used in this paper are multi-versions of Gridded Population of the World (GPW), jointly released by Columbia University, CIESIN and the NASA Socio-Economic Data and Applications Center (SEDAC).

30 Gridded Population of the World, Version 3 (GPWv3) consists of population for the years 1990, 1995, and 2000 by 2.5 arc-minutes grid cells (approximately $5 \mathrm{~km}$ at the equator) (Center for International Earth Science Information Network CIESIN - Columbia University et al., 2005). Gridded Population of the World, Version 4 (GPWv4) provides gridded population estimates with a resolution of 30 arc-seconds (approximately $1 \mathrm{~km}$ at the equator) for the years 2000, 2005, 2010, 
Nat. Hazards Earth Syst. Sci. Discuss., https://doi.org/10.5194/nhess-2018-21

Manuscript under review for journal Nat. Hazards Earth Syst. Sci.

Discussion started: 31 January 2018

(c) Author(s) 2018. CC BY 4.0 License.

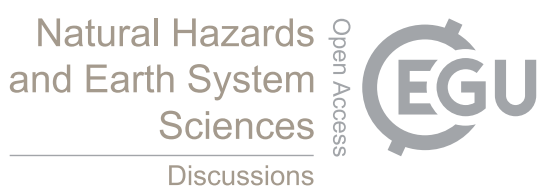

(c) (i)

2015, and 2020 (Center for International Earth Science Information Network - CIESIN - Columbia University, 2016). GPWv3 for the years of 1990 and 1995 and the whole set of GPWv4 have been used. In the data of both versions, the attribute values for each grid are the total population that lives within the grid area.

Due to the change of annual population, in this paper we calculate the population growth rate based on the data of the

5 existing years and then calculate the population distribution of each year from 1990 to 2016 based on the population growth rate of each year. The map in Fig. 2 shows population distribution in some Asian countries in 2016 and the very data was acquired by interpolating with GPWv4 2015 and 2020.

\section{Method}

The vulnerability model of people to earthquake is a model that reflects the relationship between the earthquake magnitude

10 and the earthquake casualty scale. In this paper, casualty rate $R$ (Eq.1) which defined as the ratio of casualties (the sum of deaths and injuries) to physical exposure (the total number of people living in earthquake-affected region) was used as a casualty-scale indictor.

$R=\frac{D+I}{T}$,

In the equation, $D$ is the deaths caused by the earthquake, $I$ is the number of people injured by the earthquake and $T$ is the 15 total number of people exposed to the earthquake affected area.

In this paper, earthquake-affected area is defined as the region where earthquake causes casualties, as it is often the case, shaking intensity is often VI or greater in those regions. Howell and Schultz (1975) derived attenuation equation in which shaking intensity decreases with the increase of epicentral distance from the seismological point of view, and they presented the elliptical attenuation model. Anderson (1978) and Chandra (1979) respectively analysed isoseismic data in the western 20 part of the United States and fitted the seismic intensity attenuation relationship based on the elliptic attenuation model. According to the elliptic attenuation model, the seismic intensity is positively correlated with the magnitude and negatively correlated to the epicentral distance. As for a single earthquake event, it is often in regions where shaking intensity reaches VI or even greater that casualties occurred. When the intensities of the earthquake within a radius are VI degree and above, the radius can be used to simplify the seismic intensity distribution. Based on the Bolt et al. (1977) study of strong earthquake records with different distances of epicenter, Pelling et al. (2004) determined the radius $R$ for earthquakes with different magnitudes $M$ :

When $M \leq 6.2, R=75 \mathrm{~km}$;

When $M=6.3-6.7, R=125 \mathrm{~km}$;

When $M=6.8-7.2, R=150 \mathrm{~km}$;

When $M=7.3-7.7, R=175 \mathrm{~km}$; 
Nat. Hazards Earth Syst. Sci. Discuss., https://doi.org/10.5194/nhess-2018-21

Manuscript under review for journal Nat. Hazards Earth Syst. Sci.

Discussion started: 31 January 2018

(c) Author(s) 2018. CC BY 4.0 License.

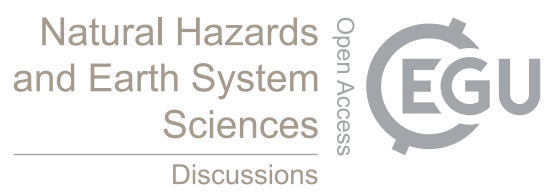

When $M \geq 7.8, R=200 \mathrm{~km}$.

In this paper, the above formula is used to determine the range of earthquake-affected area.

Flow chart of QAMECA is shown in Fig. 3. Firstly, select the population distribution data of the corresponding year according to the time of the earthquake. Secondly, determine earthquake-affected area based on earthquake magnitude and

5 the location of epicenter and then acquire physical exposure through spatial analyses and statistics in GIS software. Thirdly, casualty rate can be calculated by taking casualties and physical exposure into Equation 1. Finally, vulnerability model of people to earthquake for each country can be built with earthquake magnitude and casualty rate of corresponding earthquake data.

\section{QAMECA and verification}

10 The number of casualties caused by the earthquake is not only related to earthquake intensity and population density, but also related to the seismic performance of buildings. The seismic performance of buildings is closely related to the local economic level. Therefore, we should also consider the economic situation in this country on the construction of QAMECA. In this paper, 15 earthquake-prone Asian countries are divided into 6 groups according to their per capita GDP, which are IVI respectively. Their population and economic data are from World Bank website, shown as Table 1.

15 In this paper, we use the method of threshold curve of maximum, minimum and median casualty rate to construct the vulnerability curve of earthquake casualty in all kinds of countries. First of all, a logarithmic box diagram of a magnitude range of 0.5 is statistically compiled, and the point falling outside the solid line of the box diagram is regarded as an "abnormal point". That is, for some special reasons, the casualty rate of this earthquake is too high or too low. In curve fitting, we don't consider it. Taking the earthquake on April 14, 2010 in Yushu Tibetan Autonomous Prefecture of Qinghai

20 Province as an example, the total number of casualties caused by the earthquake was 14968. Since Yushu is located in the hinterland of the Qinghai-Tibet Plateau in the southwest of Qinghai Province, the population density is small, and the total population affected by the earthquake is only 379,000 , so the casualty rate of this earthquake is as high as $3.95 \%$, which is much higher than casualty rates of other earthquakes in China. Therefore, when we established the threshold curve of the casualty rate about earthquakes in China, we eliminated data of this earthquake. The blue lines in Fig. 4 are the threshold curves of the casualty rates of earthquakes in Asia, as shown in Table 2.

In order to verify the above threshold curve of casualty rate, we compared the real casualty data of 31 earthquakes from 2013 to 2016 with the model results, shown as Table 3.

If the actual number of casualties is between the maximum and the minimum number of casualties simulated by the model, the model simulation results are assumed to be correct. There are 21 correct results, and there are 10 results with larger errors. So we adopt the estimated deviation $D$ to measure its estimated error:

$D=\frac{M-A}{A}$, 
Nat. Hazards Earth Syst. Sci. Discuss., https://doi.org/10.5194/nhess-2018-21

Manuscript under review for journal Nat. Hazards Earth Syst. Sci.

Discussion started: 31 January 2018

(c) Author(s) 2018. CC BY 4.0 License.

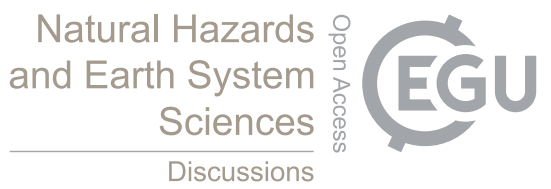

In the equation, $M$ (minimum estimate threshold value) is the estimated minimum number of casualties, and $A$ (actual value) is the actual number of casualties.

As it can be seen from Table 3, the deviations are mostly positive, which indicates that the minimum number of casualties estimated by the model is still too large. The deviation of only one earthquake is negative. It is the Ms6.1 earthquake on July

5 2nd, 2013 in Aceh, Sumatra, north-western of Indonesia. The maximum result estimated by the model is 1,350 people, which is less than the actual casualties of 2574 people. The minimum number of casualties is estimated too high, and the most of deviations are positive, that is greatly related to the accuracy of the intensity model used in this paper. According to the existing strong motion observations and hypothetical attenuation relationships, for earthquakes from magnitude of 5.5 to 8.5 at intervals of 0.5 on magnitude and at intervals of $25 \mathrm{~km}$ on the epicentral distance, Bolt et al. (1977) estimated ground

10 motion duration with acceleration greater than $0.05 \mathrm{~g}$ and vibration frequency greater than $2 \mathrm{~Hz}$. Based on this, Pelling et al. (2004) summarized the affected radius of earthquakes with different magnitudes. The radius obtained by this method might be too large, so accuracy of the model would be affected.

\section{Discussion}

The minimum curves of estimated casualty rates for the six groups of countries are compared as shown in Fig. 6.

15 Vulnerabilities are ranked in ascending order: Group I (Japan and Taiwan), Group II (Indonesia and the Philippines), Group III (China), Group IV (Afghanistan and other countries), Group V (Iran), and Group VI (Turkey). Among them, casualty rate of Group III under 6 is slightly higher than those of Group IV. Casualty rate of Group I is higher than Group II above 7.75. This may be related to some special earthquake samples in the model.

Countries in VI and V groups have the highest vulnerability, which are Turkey and Iran. This conclusion is consistent with 20 the findings of Wyss and Trendafiloski (2011). Wyss et al. considered the casualty rate (injuries/deaths) could be used as an index to measure the vulnerability of people to earthquake. If the casualty rate is larger, it means that the seismic capacity is higher and the vulnerability of population is the smaller. When the country developed from the vulnerable status to the condition with higher seismic capacity, casualty rate should increase with time. Wyss et al. studied the changes of the casualty rate in different countries from 1900 to 2010 and found that the casualty rate in Turkey and Iran kept same over

25 time. In 2005, Iran issued seismic codes for buildings, which required people to reinforce buildings with poor seismic performance by wallboard. Two earthquakes occurred consecutively on April 9 and April 16, 2013, and they showed that the seismic performance of buildings in Iran had not been significantly improved. In the earthquake of magnitude 6.3 on April 9, although magnitude of this earthquake was small and the affected areas were mostly located in sparsely populated desert, the earthquake caused 35 deaths and more than 800 injuries. There were about 920 houses in the earthquake-stricken area, among them, over 100 houses were completely destroyed and more than 500 houses were suffered various degrees of damage (Sherafati and Sohrabi, 2016). Like Iran, Turkey has had little success in improving the seismic performance of buildings. In October 2011, the earthquake of magnitude 7.2 occurred in Van Province, Turkey, where its eastern area 
Nat. Hazards Earth Syst. Sci. Discuss., https://doi.org/10.5194/nhess-2018-21

Manuscript under review for journal Nat. Hazards Earth Syst. Sci.

Discussion started: 31 January 2018

(c) Author(s) 2018. CC BY 4.0 License.

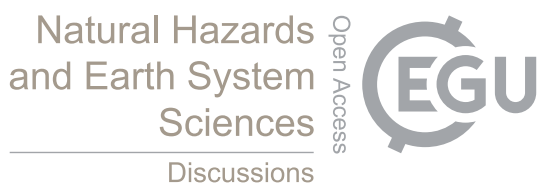

bordered on Iran, and this earthquake caused 604 deaths and 4,152 injuries. The quake occurred in the rural areas. Most of the peasants in the affected area lived in the traditional adobe houses without any reinforcement, so the massive collapse of houses was the main cause of the heavy casualties.

The countries with the least vulnerability are Japan and Taiwan as Group I in the table, for they are more perfect in 5 building seismic standards, earthquake prevention education, and earthquake early warning and so on. After the Great Kanto Earthquake in 1923, Japan amended its laws and regulations and introduced methods of seismic design and structural analysis, so Japan became the first country in the world to require seismic forces to be considered in structural calculations of buildings. After Kobe earthquake in 1995, Japan amended the Building Standards Law, which raised the seismic fortification standard of buildings and stipulated that high-rise buildings must be able to withstand strong earthquakes of

10 Ms7.0 and above. After the Great East Japan Earthquake in 2011, the Ministry of Land, Infrastructure, Transport and Tourism (MLIT) proposed to further increase the seismic capacity of housing and public facilities and improve the disaster reduction performance of government buildings (MLIT, 2011). Besides, Japan has a well-developed public earthquake early warning system (Fujinawa and Noda, 2013). At the time of the Great East Japan Earthquake in 2011, several million people near the epicentre received the earthquake early warning and had 15 to 20 seconds to prepare for the worst shaking. These measures of seismic prevention deserve other Asian countries to learn lessons.

In addition, vulnerabilities of Indonesia and the Philippines in Group II are also quite low. This is also related to a series of measures of seismic prevention and disaster reduction. In 2007, the Indonesian government introduced the Disaster Management Law to promote the former National Disaster Management Coordinating Board to an independent government agency that was Indonesian National Board for Disaster Management (BNPB). In the same year, the Indonesian government launched the National Action Plan for seismic prevention and disaster reduction, which was included in the long-term national development plan for Indonesia. In the National Action Plan, the monitoring of earthquake disasters and the allocation of early warning system were covered, and all funds required for post-disaster emergency relief should be from the annual budgets of central and local governments. The Indonesian government has vigorously promoted disaster prevention activity based on community, and initiated the Natural Disaster Volunteer Project. Till 2013, there were 20,000

25 volunteers, and most of them owned the professional technical knowledge. These volunteers not only publicize the seismic prevention and disaster reduction throughout the country, but also serve as the first responders for disaster relief and timely participate in disaster relief. To raise public awareness of the dangers and strengthen response ability with unexpected disasters, the Indonesian government actively promotes education of disaster prevention and incorporates this education into the curriculum system (Amri et al., 2017), and also provides disaster prevention education and training for teachers.

It should be pointed out that China is a country in group III. Although per capita GDP of China is higher than that of the countries in Group II, its vulnerability to earthquake is still high. This shows that the seismic performance of housing structure in China is not high. The Chinese government should learn lessons from countries in group I and II and formulate some more stringent laws and regulations of seismic prevention and disaster reduction. 
Nat. Hazards Earth Syst. Sci. Discuss., https://doi.org/10.5194/nhess-2018-21

Manuscript under review for journal Nat. Hazards Earth Syst. Sci.

Discussion started: 31 January 2018

(c) Author(s) 2018. CC BY 4.0 License.

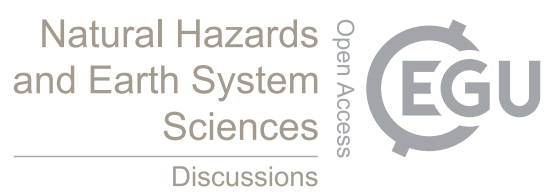

Countries in group IV, namely Afghanistan, Pakistan, India and Nepal, have high vulnerabilities, which are closely related to their economic backwardness. Sapkota et al. (2016) compared the fatality rates of the 1934 Bihar-Nepal earthquake with that of the April 2015 Gorkha earthquake, the results show that building vulnerability in urban areas has an average reduction while rural areas remained highly vulnerable after decades of earthquake prevention in Nepal. They should learn

5 lessons from countries in group II to enhance public awareness of disasters and expand disaster volunteer teams.

There are many factors that affect the number of earthquake casualties, such as the time of the earthquake, the seismic performance of the building, the emergency rescue speed, the demographic structure of the affected area and other disasters caused by the earthquake. The purpose of the model in this paper is to estimate deaths and injuries quickly, so the above factors are not considered because the data of these factors are relatively difficult to obtain.

\section{Conclusion}

In this paper, we collected the records of earthquakes disaster in Asia from 1990 to 2016 through the EM-DAT, ARDC and GLIDE databases and established the Asian Earthquake Disaster Database. The Quick Assessment Model of Earthquake Casualties for Asia (QAMECA) was developed, which was focused on the vulnerability curve of magnitude-casualty rate and was suitable for earthquake-prone countries in Asia. In this model we consider the impact of earthquake magnitude and intensity on casualties. We just need to input the two parameters of magnitude and location of epicenter and earthquake casualties can be estimated immediately after earthquake has occurred, so this model was very simple and practical. Thirtyone earthquake events from 2013 to 2016 were used to test this model, and the validation results were good in general. As a consequence, QAMECA can be used to estimate earthquake casualties for Asian countries and aid decision making about international emergency relief in the future.

20 In this paper, we also use QAMECA to evaluate the vulnerability of people to earthquake in earthquake-prone countries of Asia. Fifteen countries were classified into six groups and the vulnerabilities were listed in ascending order. They were Group I (Japan and Taiwan), Group II (Indonesia and the Philippines), Group III (China), Group IV (Afghanistan and other countries), Group V (Iran) and Group VI (Turkey). Although per capita GDP of China was higher than that of the countries in Group II, its vulnerability to earthquakes was still high. This showed that the seismic performance of housing structure in

25 China was not strong. The Chinese government should formulate some more stringent laws and regulations of seismic prevention and disaster reduction. In Afghanistan, Pakistan, India, Nepal and other countries, they should enhance public awareness of disasters and expand disaster volunteer teams. Countries that were more vulnerable to earthquakes should learn lessons from the historical earthquakes which caused heavy casualties, should learn lessons from less vulnerable countries and should continuously strengthen the earthquake prevention and disaster reduction so as to reduce the number of casualties in Asia. 
Nat. Hazards Earth Syst. Sci. Discuss., https://doi.org/10.5194/nhess-2018-21

Manuscript under review for journal Nat. Hazards Earth Syst. Sci.

Discussion started: 31 January 2018

(c) Author(s) 2018. CC BY 4.0 License.

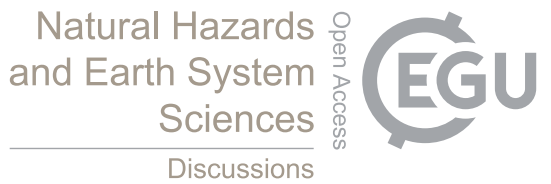

\section{Acknowledgments}

This work was supported primarily by National Key Research and Development Program Project (No.2017YFC1502505, No.2016YFA0602403), National Natural Science Foundation of China (No.41271544).

\section{References}

5 Allen, T. I., Marano, K. D., Earle, P. S., and Wald, D. J.: PA GER-CAT: A Composite Earthquake Catalog for Calibrating Global Fatality Models, Seismological Research Letters, 80, 57-62, 10.1785/gssrl.80.1.57, 2009a.

Allen, T. I., Wald, D. J., Earle, P. S., Marano, K. D., Hotovec, A. J., Lin, K., and Hearne, M. G.: An Atlas of ShakeMaps and population exposure catalog for earthquake loss modeling, Bulletin of Earthquake Engineering, 7, 701-718, 10.1007/s10518-009-9120-y, $2009 \mathrm{~b}$.

Amri, A., Bird, D. K., Ronan, K., Haynes, K., and Towers, B.: Disaster risk reduction education in Indonesia: challenges and

10 recommendations for scaling up, Natural Hazards and Earth System Sciences, 17, 595-612, 10.5194/nhess-17-595-2017, 2017.

Anderson, J. G.: Attenuation of modified Mercalli intensity with distance in the United States, Mokuzai Gakkaishi, 45, 244-250, 1978.

Bastami, M., and Soghrat, M. R.: An empirical method to estimate fatalities caused by earthquakes: the case of the Ahar-Varzaghan earthquakes (Iran), Nat. Hazards, 86, 125-149, 10.1007/s11069-016-2677-2, 2016.

Bolt, B. A., Horn, W. L., Macdonald, G. A., and Scott, R. F.: Hazards from Earthquakes, in: Geological Hazards: Earthquakes -

15 Tsunamis - Volcanoes - Avalanches - Landslides — Floods, Springer New York, New York, NY, 1-62, 1977.

Chandra, U.: Attenuation of intensities in the United States, Bulletin of the Seismological Society of America, 69, 2003-2024, 1979.

Christoskov, L., and Samardjieva, E.: An approach for estimation of the possible number of casualities during strong earthquakes, Bulgrian Geophysics, 94-106, 1984.

Frolova, N. I., Larionov, V. I., Bonnin, J., Sushchev, S. P., Ugarov, A. N., and Kozlov, M. A.: Loss caused by earthquakes: rapid estimates,

20 Nat. Hazards, 10.1007/s11069-016-2653-x, 2016.

Fujinawa, Y., and Noda, Y.: Japan's Earthquake Early Warning System on 11 March 2011: Performance, Shortcomings, and Changes, Earthquake Spectra, 29, S341-S368, 10.1193/1.4000127, 2013.

Groeve, T. D., Vernaccini, L., Annunziato, A., and Gadenz, S.: Real-time impact estimation of large earthquakes using USGS Shakemaps, 2008.

25 Howell, B. F., and Schultz, T. R.: Attenuation of Modified Mercalli Intensity with distance from the epicenter, Bulletin of the Seismological Society of America, 651-665, 1975.

Jaiswal, K., and Wald, D.: An Empirical Model for Global Earthquake Fatality Estimation, Earthquake Spectra, 26, 1017-1037, $10.1193 / 1.3480331,2010$.

Jaiswal, K. S., Wald, D. J., Earle, P. S., Porter, K. A., and Hearne, M.: Earthquake Casualty Models Within the USGS Prompt Assessment

30 of Global Earthquakes for Response (PAGER) System, in: Human Casualties in Earthquakes: Progress in Modelling and Mitigation, edited by: Spence, R., So, E., and Scawthorn, C., Springer Netherlands, Dordrecht, 83-94, 2011.

MLIT: MLIT Recovery and Rehabilitation Plan in response to the Great East Japan Earthquake, http://www.mlit.go.jp/common/000161202.pdf, 2011

Nichols, J. M., and Beavers, J. E.: Development and Calibration of an Earthquake Fatality Function, Earthquake Spectra, 19, 605-633, 35 10.1193/1.1596916, 2003.

Pelling, M., Maskrey, A., Ruiz, P., Hall, P., Peduzzi, P., Dao, Q.-H., Mouton, F., Herold, C., and Kluser, S.: Reducing Disaster Risk: a challenge for development, United Nations, New York978-92-1-126160-8, 2004.

Samardjieva, E., and Badal, J.: Estimation of the expected number of casualties caused by strong earthquakes, Bulletin of the Seismological Society of America, 92, 2310-2322, 10.1785/0120010112, 2002.

40 Sapkota, S. N., Bollinger, L., and Perrier, F.: Fatality rates of the M w $\sim 8.2,1934$, Bihar-Nepal earthquake and comparison with the April 2015 Gorkha earthquake, Earth, Planets and Space, 68, 40, 10.1186/s40623-016-0416-2, 2016.

Sherafati, M. A., and Sohrabi, M. R.: Performance of Masonry Walls during Kaki, Iran, Earthquake of April 9, 2013, J Perform Constr Fac, 30, 2016 .

Trendafiloski, G., Wyss, M., and Rosset, P.: Loss Estimation Module in the Second Generation Software QLARM, in: Human Casualties

45 in Earthquakes: Progress in Modelling and Mitigation, edited by: Spence, R., So, E., and Scawthorn, C., Springer Netherlands, Dordrecht, 95-106, 2011.

Wyss, M., and Trendafiloski, G.: Trends in the Casualty Ratio of Injured to Fatalities in Earthquakes, in: Human Casualties in Earthquakes: Progress in Modelling and Mitigation, edited by: Spence, R., So, E., and Scawthorn, C., Springer Netherlands, Dordrecht, 267-274, 2011. 
Nat. Hazards Earth Syst. Sci. Discuss., https://doi.org/10.5194/nhess-2018-21

Manuscript under review for journal Nat. Hazards Earth Syst. Sci.

Discussion started: 31 January 2018

(c) Author(s) 2018. CC BY 4.0 License.

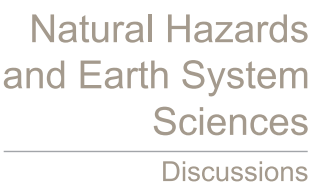

(c) (1)

Table 1 Basic information and classification of earthquake-prone countries in Asia

\begin{tabular}{|c|c|c|c|c|c|}
\hline \multirow{2}{*}{ Group } & $\begin{array}{c}\text { Country } \\
\text { (Region) }\end{array}$ & $\begin{array}{c}\text { GDP } \\
\text { (billion US\$) }\end{array}$ & $\begin{array}{c}\text { Population } \\
(100 \text { million) }\end{array}$ & $\begin{array}{c}\text { Per Capita } \\
\text { GDP(US\$) }\end{array}$ & $\begin{array}{c}\text { Average number of } \\
\text { casualties per time }\end{array}$ \\
\hline \multirow{3}{*}{ I } & Japan & 4383 & 1.27 & 34523 & 2903 \\
\cline { 2 - 6 } & Taiwan & 524 & 0.23 & 22288 & 2305 \\
\cline { 2 - 6 } & Indonesia & 861 & 2.57 & 3346 & 5317 \\
\hline \multirow{2}{*}{ III } & Philippines & 293 & 1.01 & 2904 & 586 \\
\hline \multirow{7}{*}{} & China & 11065 & 13.71 & 8069 & 6195 \\
\cline { 2 - 6 } & Afghanistan & 20 & 0.34 & 594 & 765 \\
\cline { 2 - 6 } & Pakistan & 271 & 1.89 & 1435 & 170 \\
\cline { 2 - 6 } & India & 2112 & 13.26 & 1593 & 25786 \\
\cline { 2 - 6 } & Nepal & 213 & 2.87 & 743 & 15634 \\
\cline { 2 - 6 } & Kyrgyzstan & 7 & 0.06 & 1103 & 47 \\
\cline { 2 - 6 } & Tajikistan & 8 & 0.09 & 926 & 152 \\
\hline & Bengal & 195 & 1.61 & 1212 & 118 \\
\cline { 2 - 6 } & Myanmar & 63 & 0.54 & 1161 & 4674 \\
\hline \multirow{2}{*}{ V } & Iran & 393 & 0.72 & 5443 & 3212 \\
\hline VI & Turkey & 859 & 0.94 & 9126 & \\
\hline
\end{tabular}


Nat. Hazards Earth Syst. Sci. Discuss., https://doi.org/10.5194/nhess-2018-21

Manuscript under review for journal Nat. Hazards Earth Syst. Sci.

Discussion started: 31 January 2018

(c) Author(s) 2018. CC BY 4.0 License.

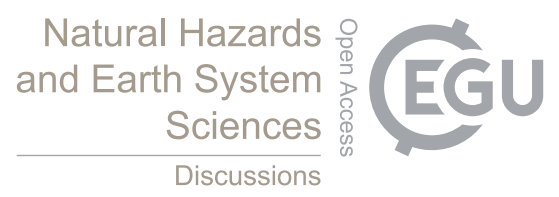

(c) (1)

Table 2 Magnitude-Casualty Rate Threshold Curve Equations in Some Asian Countries

\begin{tabular}{|c|c|c|c|c|}
\hline \multirow{3}{*}{ Group } & \multirow{3}{*}{$\begin{array}{l}\text { Country } \\
\text { (Region) }\end{array}$} & Maximum & \multirow{3}{*}{$\mathrm{R}^{2}$} & \multirow{3}{*}{ P-value } \\
\hline & & Median & & \\
\hline & & Minimum & & \\
\hline \multirow{3}{*}{ I } & \multirow{3}{*}{$\begin{array}{c}\text { Japan and } \\
\text { Taiwan }\end{array}$} & $y=-70.04 x^{-1.687}$ & 0.86 & 0.02250 \\
\hline & & $y=-28.96 x^{-1.048}$ & 0.85 & 0.00236 \\
\hline & & $y=-22.45 x^{-0.775}$ & 0.83 & 0.00408 \\
\hline \multirow{3}{*}{ II } & Indonesia & $y=-70.02 x^{-1.727}$ & 0.81 & 0.00752 \\
\hline & and & $\mathrm{y}=-17.34 x^{-0.821}$ & 0.89 & 0.00044 \\
\hline & Philippines & $y=-9.20 x^{-0.340}$ & 0.77 & 0.00154 \\
\hline \multirow{3}{*}{ III } & \multirow{3}{*}{ China } & $y=-11.80 x^{-0.884}$ & 0.82 & 0.00229 \\
\hline & & $y=-8.30 x^{-0.464}$ & 0.75 & 0.00551 \\
\hline & & $y=-11.50 x^{-0.492}$ & 0.79 & 0.00296 \\
\hline \multirow{3}{*}{ IV } & Afghanistan & $y=-244.80 x^{-2.458}$ & 0.96 & 0.00003 \\
\hline & and other & $y=-30.54 x^{-1.152}$ & 0.91 & 0.00007 \\
\hline & countries & $\mathrm{y}=-15.11 x^{-0.644}$ & 0.91 & 0.00322 \\
\hline \multirow{3}{*}{$\mathrm{V}$} & \multirow{3}{*}{ Iran } & $y=-177.20 x^{-2.341}$ & 0.96 & 0.00056 \\
\hline & & $y=-32.39 x^{-1.241}$ & 0.96 & 0.00023 \\
\hline & & $y=-19.04 x^{-0.840}$ & 0.87 & 0.00743 \\
\hline \multirow{3}{*}{ VI } & \multirow{3}{*}{ Turkey } & $\mathrm{y}=-17.81 x^{-1.070}$ & 0.94 & 0.03020 \\
\hline & & $y=-21.99 x^{-1.017}$ & 0.87 & 0.00248 \\
\hline & & $y=-25.18 x^{-1.021}$ & 0.81 & 0.03770 \\
\hline
\end{tabular}

(* $\mathrm{x}$ is magnitude, $\mathrm{y}$ is the logarithm of casualty rate with base 10 )

5

10

15 
Nat. Hazards Earth Syst. Sci. Discuss., https://doi.org/10.5194/nhess-2018-21

Manuscript under review for journal Nat. Hazards Earth Syst. Sci.

Discussion started: 31 January 2018

(c) Author(s) 2018. CC BY 4.0 License.
Natural Hazards

and Earth System

Sciences

Discussions

(c) (i)

Table 3 Verification Table of Casualty Rate Threshold Curve

\begin{tabular}{|c|c|c|c|c|c|c|c|}
\hline \multirow{2}{*}{ Group } & \multirow{2}{*}{ Country } & \multirow{2}{*}{$\begin{array}{c}\text { Magnit } \\
\text { ude }\end{array}$} & \multirow{2}{*}{$\begin{array}{c}\text { Actual } \\
\text { number of } \\
\text { casualties }\end{array}$} & \multicolumn{3}{|c|}{ Estimated number of casualties } & \multirow{2}{*}{$\begin{array}{l}\text { Estimated } \\
\text { deviation }\end{array}$} \\
\hline & & & & Maximum & Median & Minimum & \\
\hline \multirow{5}{*}{ I } & \multirow{4}{*}{ Japan } & 6.3 & 32 & 5611 & 479 & 32 & 1 \\
\hline & & 6.7 & 45 & 10388 & 797 & 51 & $13.3 \%$ \\
\hline & & 6.5 & 2853 & 11161 & 899 & 58 & I \\
\hline & & 6.6 & 30 & 7248 & 569 & 37 & $23.3 \%$ \\
\hline & Taiwan & 6.4 & 559 & 7287 & 603 & 39 & 1 \\
\hline \multirow{4}{*}{ II } & \multirow{3}{*}{ Indonesia } & 6.1 & 2574 & 1350 & 195 & 19 & $-99.3 \%$ \\
\hline & & 6.5 & 32 & 4528 & 489 & 36 & $12.5 \%$ \\
\hline & & 6.4 & 491 & 3398 & 391 & 30 & I \\
\hline & Philippines & 7.2 & 1018 & 31799 & 2447 & 131 & 1 \\
\hline \multirow{9}{*}{ III } & \multirow{9}{*}{ China } & 5.0 & 14 & 2775 & 227 & 12 & $/$ \\
\hline & & 7.0 & 13680 & 285589 & 15981 & 1425 & I \\
\hline & & 6.6 & 1095 & 52604 & 3080 & 253 & / \\
\hline & & 5.9 & 47 & 789 & 52 & 4 & / \\
\hline & & 6.1 & 43 & 10146 & 640 & 47 & $9.3 \%$ \\
\hline & & 6.5 & 3760 & 44286 & 2627 & 211 & / \\
\hline & & 6.6 & 325 & 20472 & 1199 & 99 & l \\
\hline & & 6.3 & 59 & 5161 & 315 & 25 & / \\
\hline & & 6.4 & 52 & 6316 & 380 & 30 & 1 \\
\hline \multirow{9}{*}{ IV } & \multirow{3}{*}{ Afghanistan } & 5.7 & 159 & 1274 & 245 & 38 & 1 \\
\hline & & 7.5 & 639 & 273498 & 14745 & 1093 & $71 \%$ \\
\hline & & 6.2 & 12 & 808 & 87 & 11 & 1 \\
\hline & \multirow{3}{*}{ Pakistan } & 7.7 & 974 & 183776 & 9488 & 672 & I \\
\hline & & 7.5 & 2025 & 148789 & 8022 & 595 & I \\
\hline & & 6.6 & 46 & 6719 & 527 & 52 & $13 \%$ \\
\hline & Nepal & 7.8 & 31212 & 1010082 & 55797 & 3865 & 1 \\
\hline & \multirow{2}{*}{ India } & 5.8 & 60 & 5526 & 922 & 134 & $123.3 \%$ \\
\hline & & 6.7 & 211 & 44075 & 3255 & 308 & $46 \%$ \\
\hline \multirow{4}{*}{$\mathrm{V}$} & \multirow{4}{*}{ Iran } & 6.3 & 835 & 4417 & 536 & 94 & / \\
\hline & & 7.8 & 114 & 38091 & 3129 & 433 & $279.8 \%$ \\
\hline & & 5.6 & 52 & 361 & 76 & 17 & / \\
\hline & & 6.1 & 60 & 1763 & 242 & 45 & 1 \\
\hline
\end{tabular}

5 
Nat. Hazards Earth Syst. Sci. Discuss., https://doi.org/10.5194/nhess-2018-21

Manuscript under review for journal Nat. Hazards Earth Syst. Sci.

Discussion started: 31 January 2018

(c) Author(s) 2018. CC BY 4.0 License.

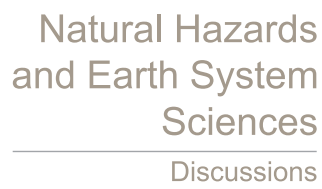

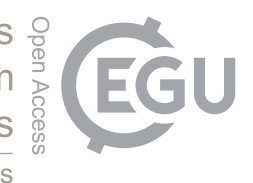

(c) (1)

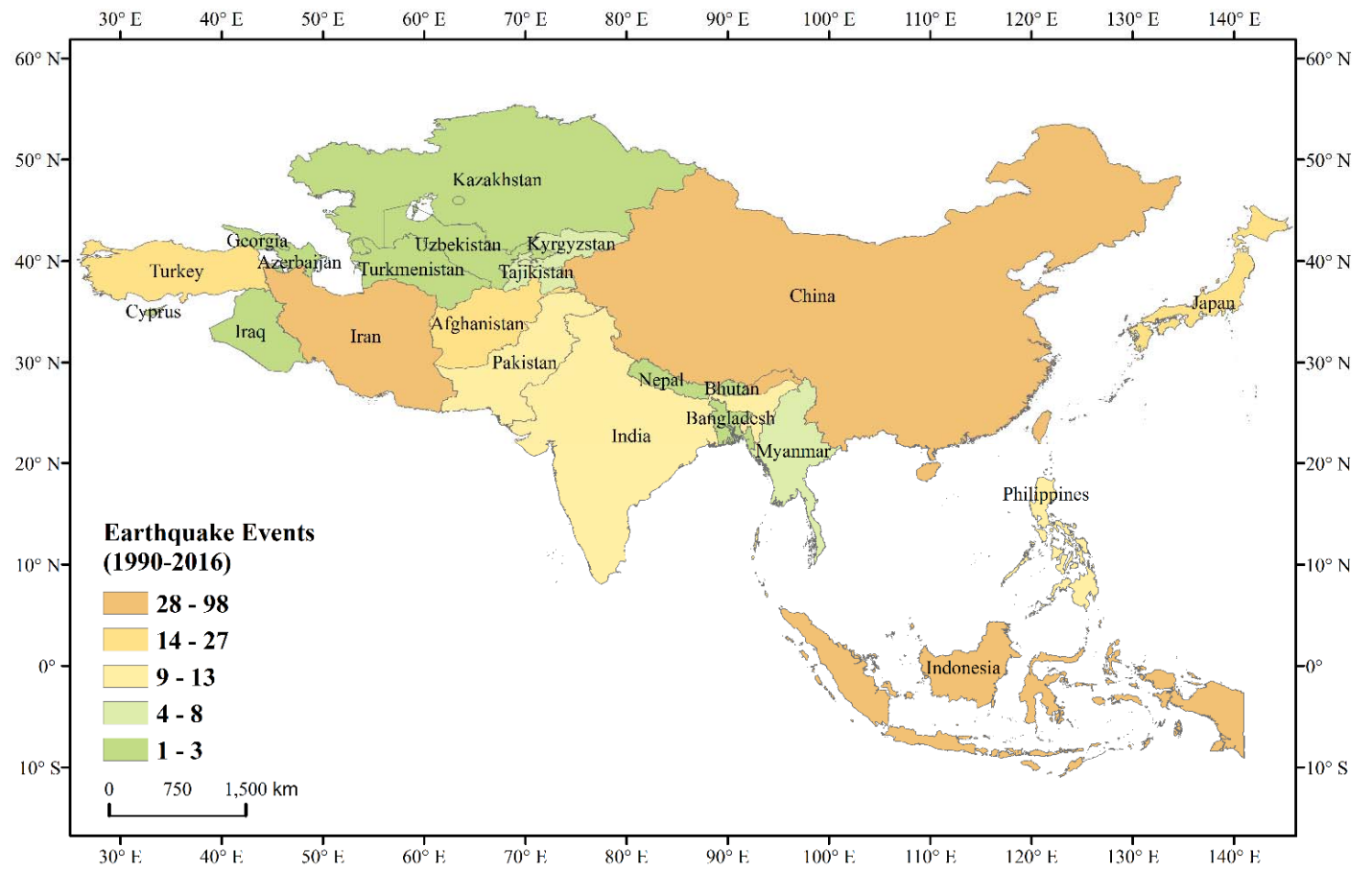

Figure 1 Number of earthquakes with magnitude no less than 5.0 in Asian countries 
Nat. Hazards Earth Syst. Sci. Discuss., https://doi.org/10.5194/nhess-2018-21

Manuscript under review for journal Nat. Hazards Earth Syst. Sci.

Discussion started: 31 January 2018

(c) Author(s) 2018. CC BY 4.0 License.

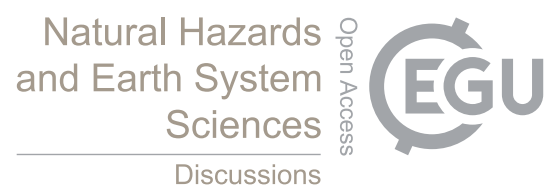

(c) (i)

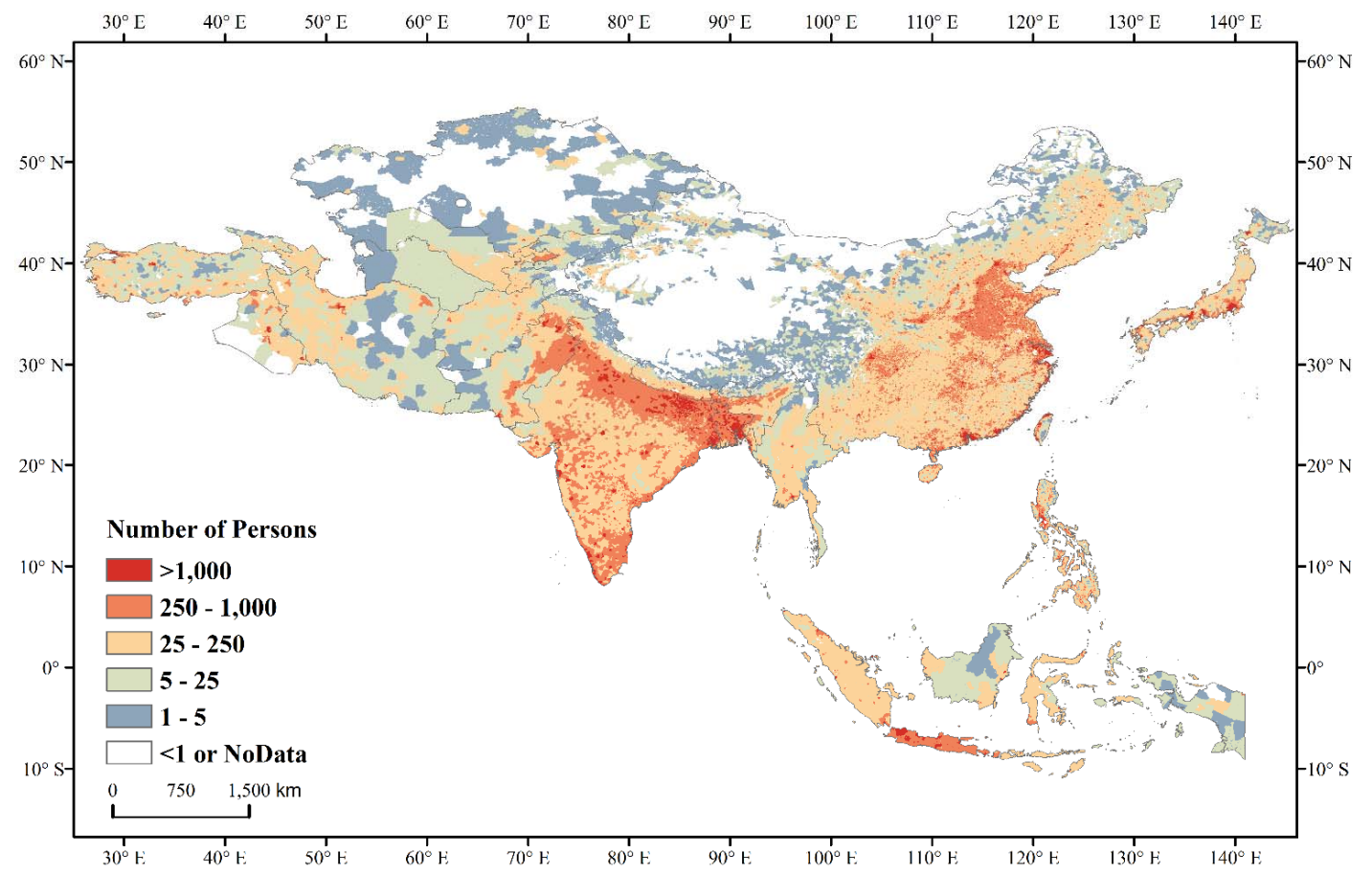

Figure 2 Asian population distribution in 2016 
Nat. Hazards Earth Syst. Sci. Discuss., https://doi.org/10.5194/nhess-2018-21

Manuscript under review for journal Nat. Hazards Earth Syst. Sci.

Discussion started: 31 January 2018

(c) Author(s) 2018. CC BY 4.0 License.

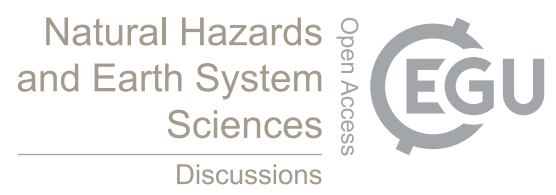

(c) (i)

5

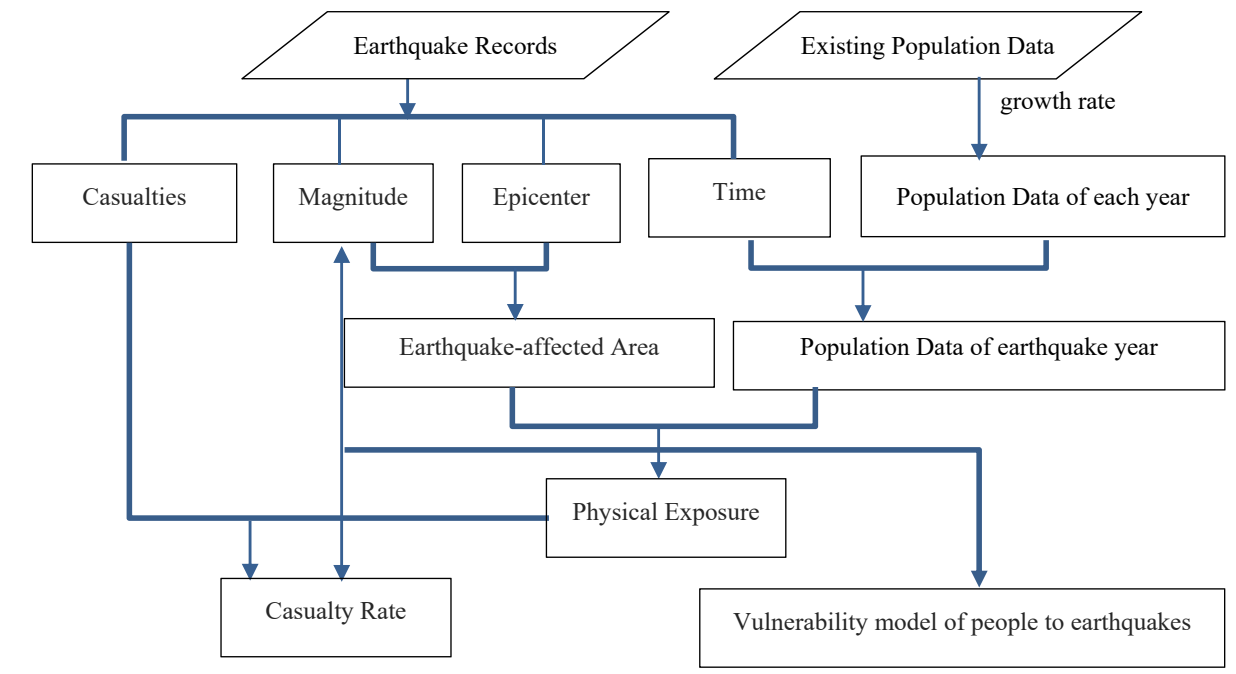

15

Figure 3 Flow chart of QAMECA

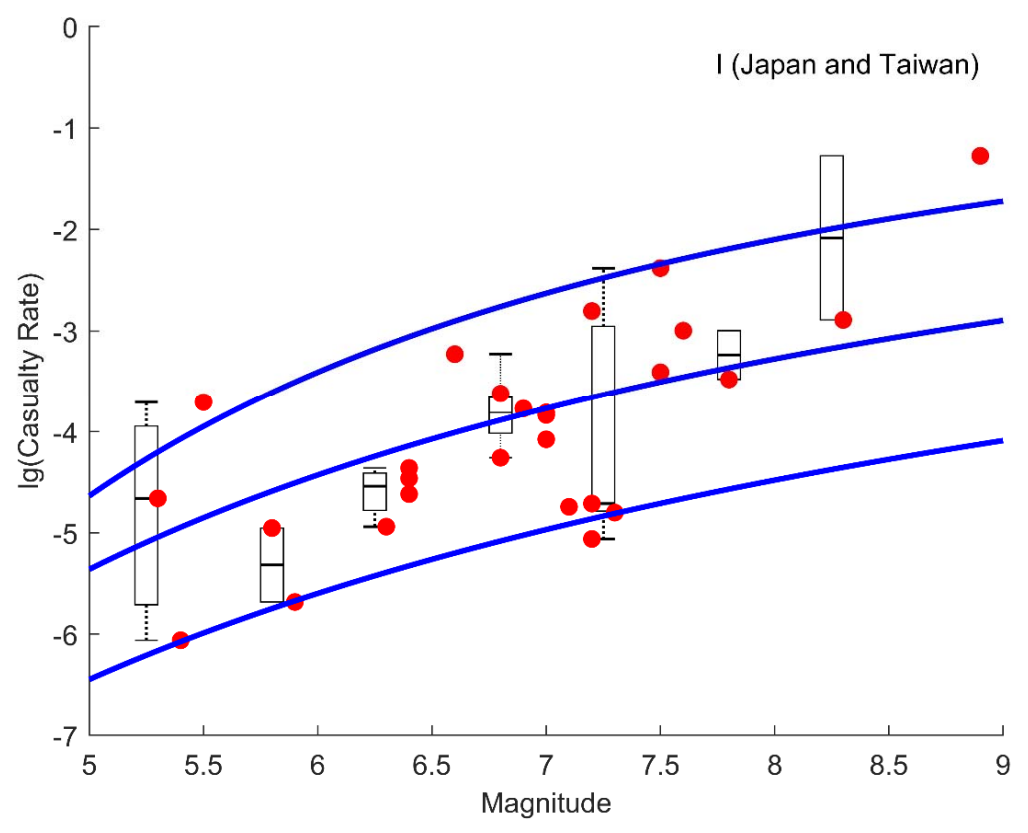


Nat. Hazards Earth Syst. Sci. Discuss., https://doi.org/10.5194/nhess-2018-21

Manuscript under review for journal Nat. Hazards Earth Syst. Sci.

Discussion started: 31 January 2018

(c) Author(s) 2018. CC BY 4.0 License.

(c) (i)

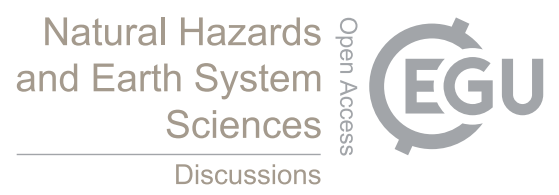

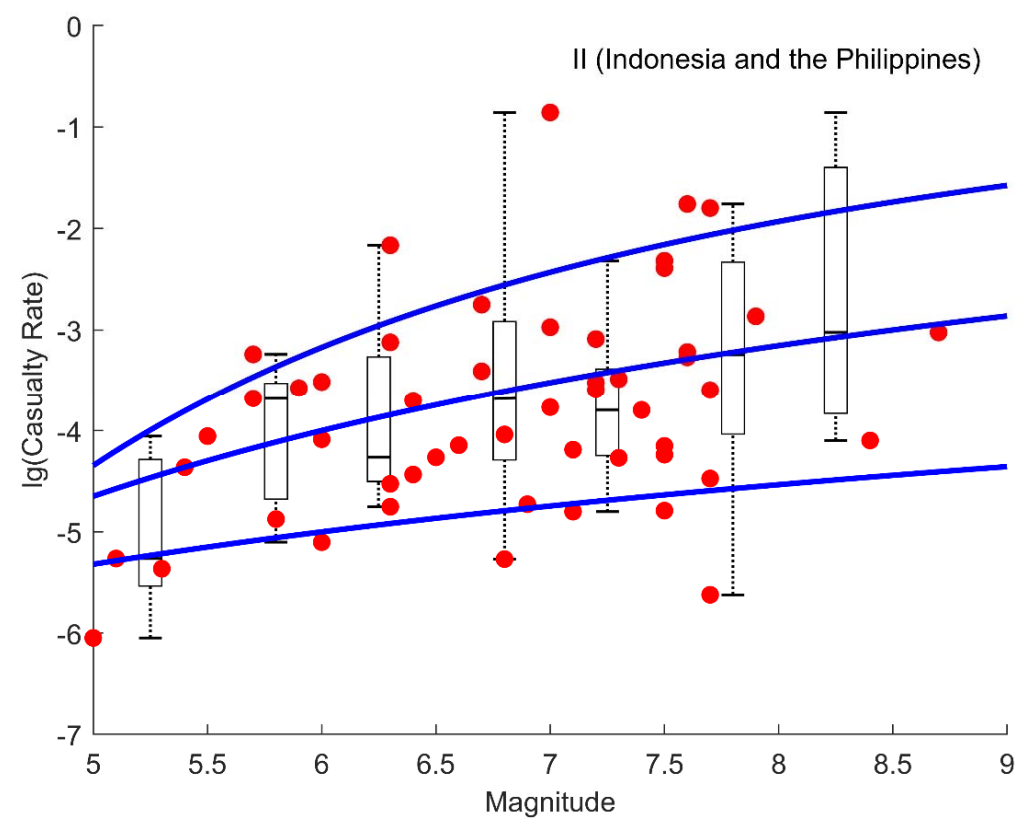


Nat. Hazards Earth Syst. Sci. Discuss., https://doi.org/10.5194/nhess-2018-21

Manuscript under review for journal Nat. Hazards Earth Syst. Sci.

Discussion started: 31 January 2018

(c) Author(s) 2018. CC BY 4.0 License.

(c) (i)

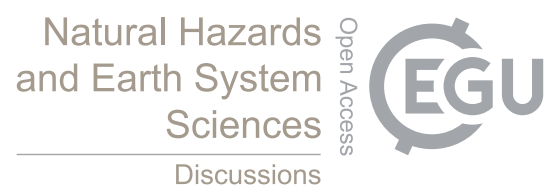

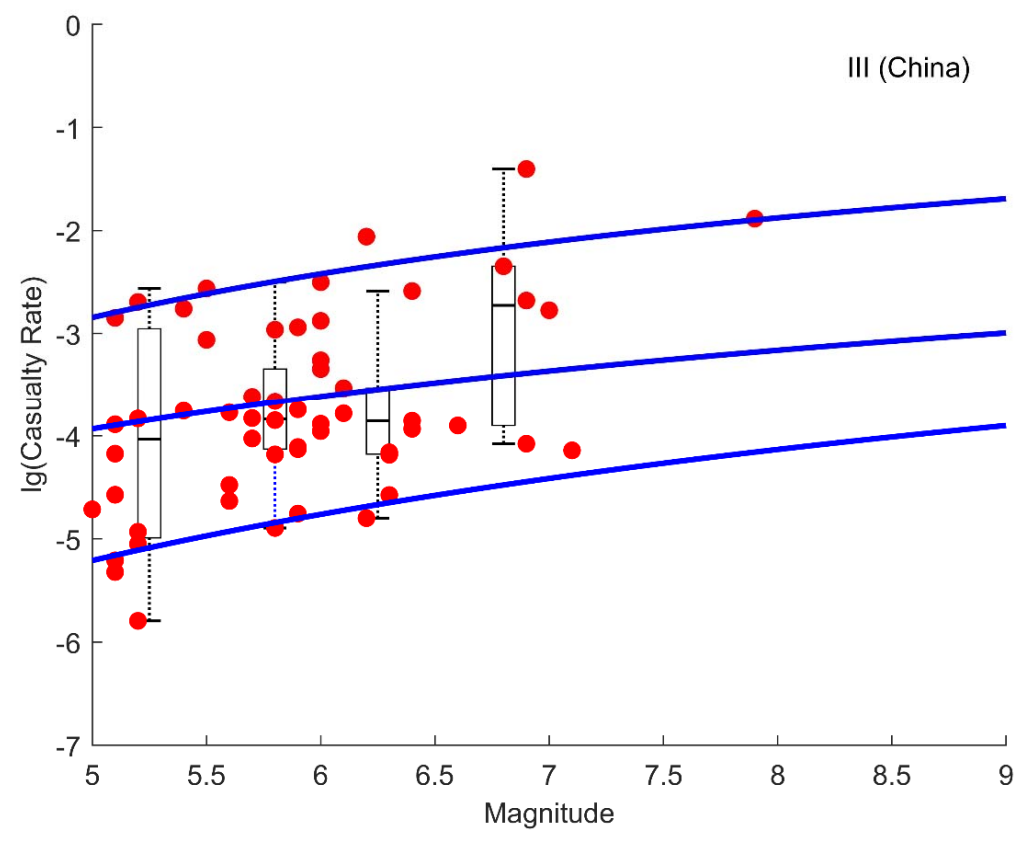


Nat. Hazards Earth Syst. Sci. Discuss., https://doi.org/10.5194/nhess-2018-21

Manuscript under review for journal Nat. Hazards Earth Syst. Sci.

Discussion started: 31 January 2018

(c) Author(s) 2018. CC BY 4.0 License.

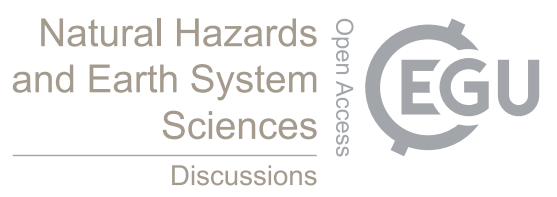

(c) (i)

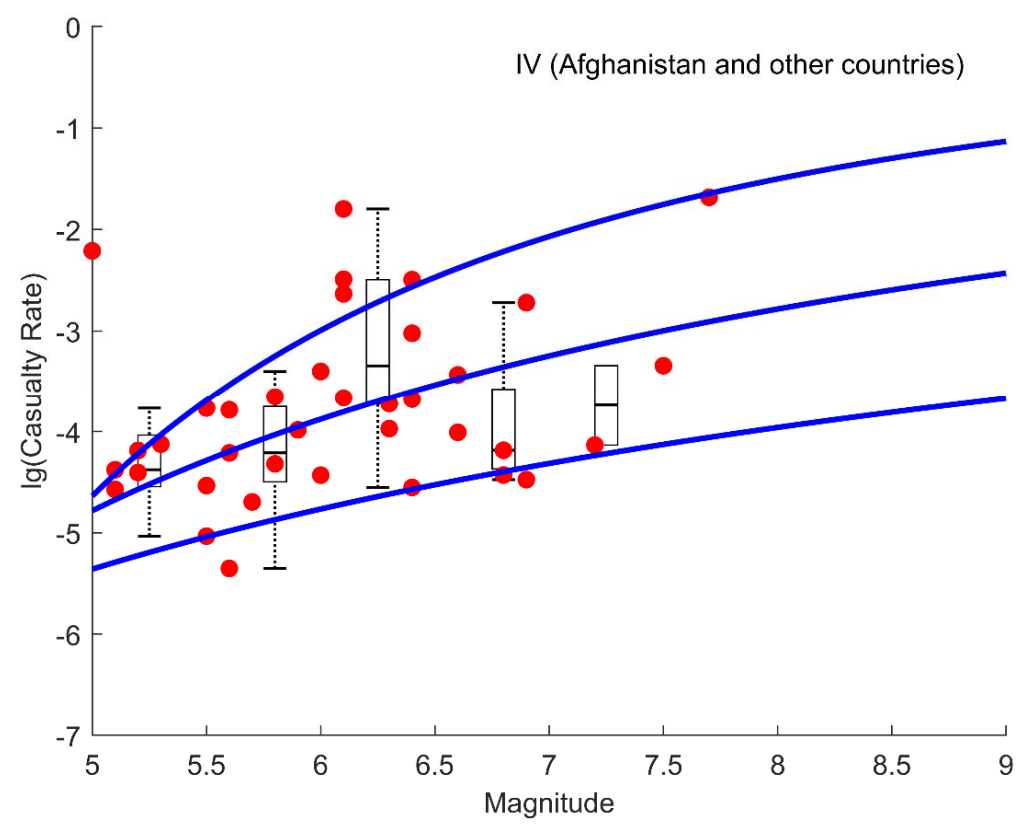


Nat. Hazards Earth Syst. Sci. Discuss., https://doi.org/10.5194/nhess-2018-21

Manuscript under review for journal Nat. Hazards Earth Syst. Sci.

Discussion started: 31 January 2018

(c) Author(s) 2018. CC BY 4.0 License.

\section{(c) (i)}

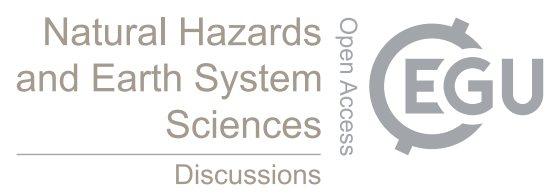

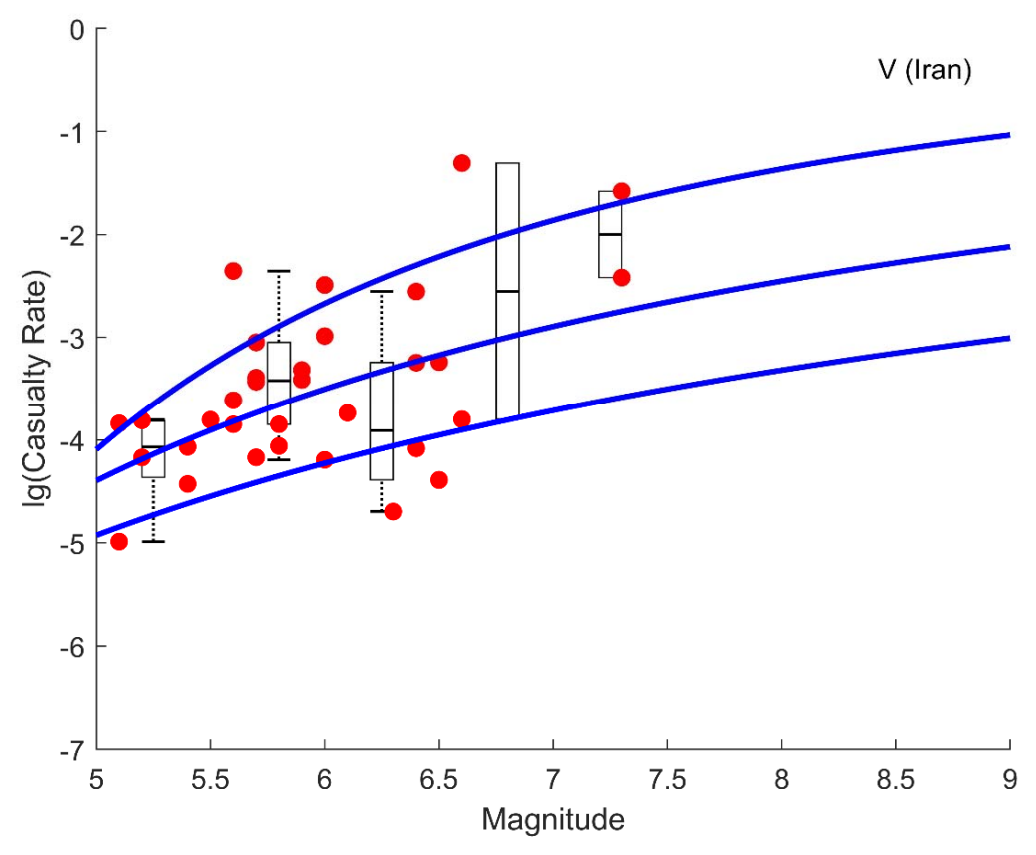


Nat. Hazards Earth Syst. Sci. Discuss., https://doi.org/10.5194/nhess-2018-21

Manuscript under review for journal Nat. Hazards Earth Syst. Sci.

Discussion started: 31 January 2018

(c) Author(s) 2018. CC BY 4.0 License.

(c) (i)

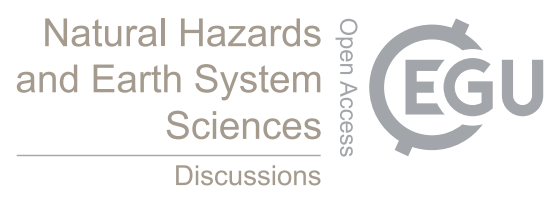

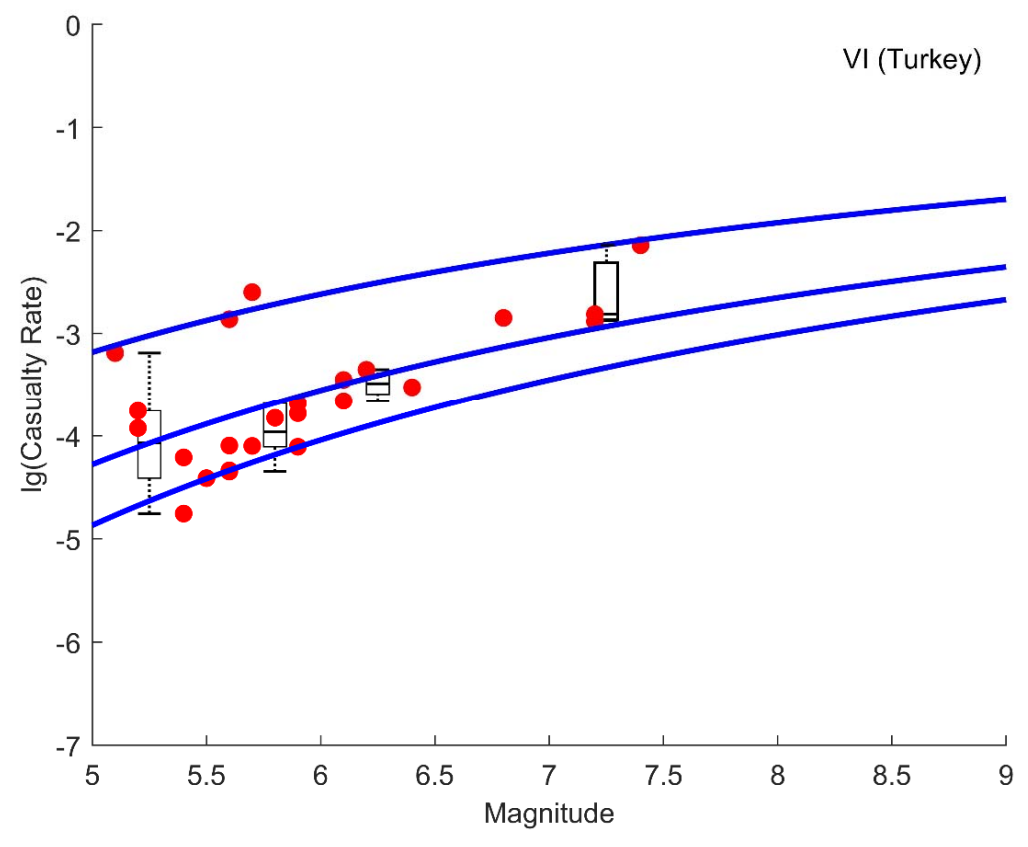

Figure 4 Magnitude-casualty rate threshold curve in some Asian countries 
Nat. Hazards Earth Syst. Sci. Discuss., https://doi.org/10.5194/nhess-2018-21

Manuscript under review for journal Nat. Hazards Earth Syst. Sci.

Discussion started: 31 January 2018

(c) Author(s) 2018. CC BY 4.0 License.

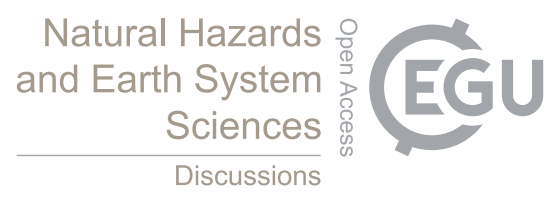

(c)

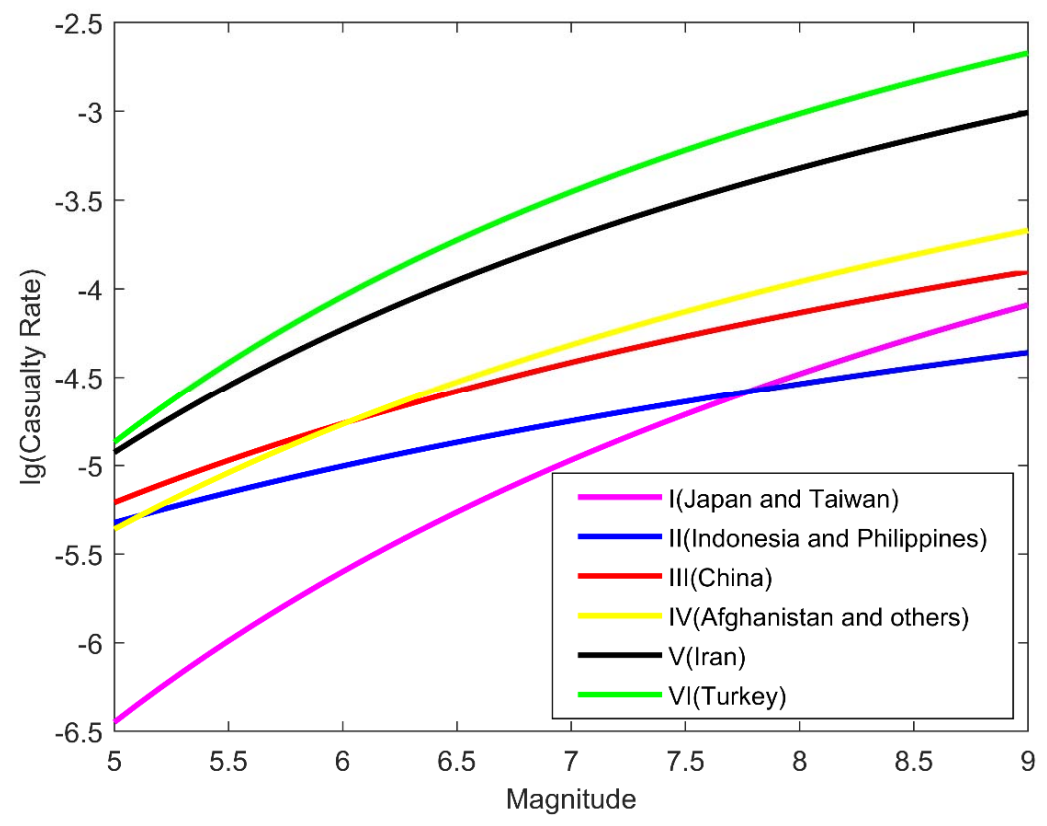

Figure 5 Minimum curves of estimated casualty rate 